\title{
Knowledge of Farmers Regarding Information and Communication Technology
}

\author{
G. Sriker Reddy*, S. L. Deotale and S. D. Mane \\ Department of Extension Education, College of Agriculture, Nagpur, India \\ *Corresponding author
}

\section{A B S T R A C T}

\section{Keywords}

Knowledge, Information and Communication technology

\section{Article Info}

Accepted:

16 November 2020

Available Online:

10 December 2020
ICT stands for Information and Communication Technology which can be broadly explained as technologies that facilitate communication, processing and transmission of information by electronic means, it can be considered as term that includes the use of any device from mobile phones\& computer to ATMs. The present study on Attitude of farmers towards Information and Communication technology in Wardha district of Maharashtra state with a sample size of 120 farmers selected from 10 different villages of two tahsils. Vast majority of the selected respondents for the respective study had knowledge about Information and communication technology, As it is observed that 100 per cent respondents said Yes to the statement do you get agriculture information from television followed by 99.16 per cent of them said Yes to the statement Do you get agriculture information in mobile and majority of them said No the statement Documentaries, CDs/DVDs etc. provide you detailed information with clear audio and video. In overall majority of them 52.50 per cent of them were under medium category of knowledge about ICT.

\section{Introduction}

Information and Communication Technology (ICT) can bring new information services to the rural areas where the farmer (end user) will have much control than ever before over the current information channels. Access to such information sources is a crucial requirement for the sustainable development of the farming systems.

The unprecedented development of ICT, its application, and the emergence of a global information society are changing the way people live, learn, work and interact.
Enhanced access to knowledge is rapidly becoming is rapidly becoming a potent tool for empowering the people and communities in their quest for new opportunities, dignity and a better life.

Traditional media have been used very successfully in developing countries, and rural radio in particular has played major role in delivering agricultural messages. Print, video, television, films, slides, pictures, dramas, exhibitions, etc...have also been used to speed up the flow of information (Munyua, 2000). 


\section{Materials and Methods}

The study was conducted in Wardha district of Maharashtra State. Two tahsils of Wardha district namely Deoli and wardha were selected for the study. Five villages were selected purposively from each tehsil considering the availability of ICT tools and its utilization. Thus, accordingly ten villages were taken up for the study and a total of 120 respondents were selected. The exploratory research design was used for the study. The data were collected in face-to-face situation by the personal interview method with the help of structured interview schedule. The data were tabulated, analysed and the results were interpreted (Table 1).

\section{Results and Discussion}

The findings of the study had been presented under the following headings.

\section{Knowledge of farmers towards ICT}

The data in Table 1 further revealed that majority them i.e. 100 per cent of respondents accepted that they get agriculture information through television (T.V) followed by 99.16 per cent and 95 per cent of them get agriculture information through mobile phones and telephone, respectively. Remainning 0.83 per cent and 5 per cent of them didn't get agriculture information through mobile and telephone. While large number (60\%) of them doesn't get agriculture information through CDs/DVDs only 40 per cent of them get information through CDs/DVDs. And through internet 91.66 per cent of the respondents are getting agriculture information rest 8.33 per cent are didn't getting through it. More than $2 / 3^{\text {rd }}$ i.e. 61.66 per cent of them has accepted that video conferencing provides them agriculture information and rest 38.33 per cent of them rejected the statement.
It was evident from the findings that more than $2 / 3^{\text {rd }}$ i.e. about $70 \%$ of the respondents accepted that video conferencing is a two-way communication process and $30 \%$ of them rejected this statement. More than $50 \%$ of the respondents i.e. 53.33 per cent of them were not at a point of acceptance that CDs/DVDs and documentaries are providing clear and detailed audio video information and rest $46.66 \%$ were have been accepting that statement.

Majority of the respondents i.e. 91.66 per cent of them considered that ICT tools as a source for retrieving their data and remaining 8.33 per cent of them rejected this statement. About 90 per cent of the respondents believed that ICT tools will provide information related to crop production, crop protection, post-harvest technologies and other activities and 10 per cent of them were not in a point of acceptance.

ICT tools can provide you with agriculture's, marketing and storage related information as 83.33 per cent of them believed in this point and rest $(15.66 \%)$ of them has denied that they get that information through ICT tools. More than 3/4th of the respondents i.e. 80\% of them accepted that ICT tools provide information regarding government policies, programme, and crop insurance schemes and remaining $20 \%$ of them has not accepted this statement.

\section{Overall knowledge level}

Data presented in Table 2 shows that majority of the farmers (52.50\%) of them were having medium level of knowledge about ICT and its tools followed by $(40.83 \%)$ of the farmers who were highly knowledged about ICT and its tools and $(6.66 \%)$ of them were having low level knowledge about ICT. These findings are in conformity with the findings of K.P Raghu Prasad et al., (2013), Devaraja (2011). 
Table.1 Distribution of respondents according to their knowledge about ICT

\begin{tabular}{|c|c|c|c|}
\hline \multirow{2}{*}{$\begin{array}{l}\text { Sr. } \\
\text { No }\end{array}$} & \multirow[t]{2}{*}{ Statements } & Yes & No \\
\hline & & $\begin{array}{c}\text { Respondents } \\
(\%)\end{array}$ & $\begin{array}{c}\text { Respondents } \\
(\%)\end{array}$ \\
\hline 1. & $\begin{array}{l}\text { Do you get agricultural information } \\
\text { from television? }\end{array}$ & $\begin{array}{c}120 \\
(100)\end{array}$ & $\begin{array}{c}0 \\
(0)\end{array}$ \\
\hline 2. & $\begin{array}{l}\text { Do you get agricultural information } \\
\text { through mobile phone? }\end{array}$ & $\begin{array}{c}119 \\
(99.16)\end{array}$ & $\begin{array}{c}01 \\
(0.84)\end{array}$ \\
\hline 3. & $\begin{array}{l}\text { Do radio provide agriculture } \\
\text { information }\end{array}$ & $\begin{array}{c}98 \\
(81.66)\end{array}$ & $\begin{array}{c}22 \\
(18.33)\end{array}$ \\
\hline 4. & $\begin{array}{l}\text { Whether internet provide you } \\
\text { agriculture related information? }\end{array}$ & $\begin{array}{c}110 \\
(91.66)\end{array}$ & $\begin{array}{c}10 \\
(8.33)\end{array}$ \\
\hline 5. & $\begin{array}{l}\text { Do you get agriculture related } \\
\text { information through } \\
\text { Videoconference? }\end{array}$ & $\begin{array}{c}74 \\
(61.66)\end{array}$ & $\begin{array}{c}46 \\
(38.33)\end{array}$ \\
\hline 6. & $\begin{array}{l}\text { Video conferencing is a two-way } \\
\text { communication }\end{array}$ & $\begin{array}{c}84 \\
(70.00)\end{array}$ & $\begin{array}{c}36 \\
(30.00)\end{array}$ \\
\hline 7. & $\begin{array}{l}\text { Whether telephone provides you } \\
\text { agriculture information? }\end{array}$ & $\begin{array}{c}114 \\
(95.00)\end{array}$ & $\begin{array}{c}06 \\
(5.00)\end{array}$ \\
\hline 8. & $\begin{array}{l}\text { Do you get agriculture information } \\
\text { from CDs/DVDs etc.? }\end{array}$ & $\begin{array}{c}48 \\
(40.00)\end{array}$ & $\begin{array}{c}72 \\
(60.00)\end{array}$ \\
\hline \multirow[b]{2}{*}{$\begin{array}{l}\text { Sr. } \\
\text { No }\end{array}$} & \multirow[b]{2}{*}{ Statements } & Yes & No \\
\hline & & $\begin{array}{l}\text { Respondents } \\
(\%)\end{array}$ & $\begin{array}{c}\text { Respondents } \\
(\%)\end{array}$ \\
\hline 9. & $\begin{array}{l}\text { Documentaries, CDs/DVDs etc. } \\
\text { provide you detailed information } \\
\text { with clear audio and video }\end{array}$ & $\begin{array}{c}56 \\
(46.66)\end{array}$ & $\begin{array}{c}64 \\
(53.33)\end{array}$ \\
\hline 10. & ICT tools provide retrievable data & $\begin{array}{c}110 \\
(91.66)\end{array}$ & $\begin{array}{c}10 \\
(8.33)\end{array}$ \\
\hline 11. & $\begin{array}{l}\text { ICT tools provide information } \\
\text { related to crop production, crop } \\
\text { protection, post-harvest } \\
\text { technologies and other activities }\end{array}$ & $\begin{array}{c}108 \\
(90.00)\end{array}$ & $\begin{array}{c}12 \\
(10.00)\end{array}$ \\
\hline 12. & $\begin{array}{l}\text { ICT tools provide you with } \\
\text { agricultures, marketing and storage } \\
\text { related information }\end{array}$ & $\begin{array}{c}100 \\
(83.33)\end{array}$ & $\begin{array}{c}20 \\
(16.66)\end{array}$ \\
\hline 13. & $\begin{array}{l}\text { Do you accept ICT as a quick mode } \\
\text { of communication process? }\end{array}$ & $\begin{array}{c}102 \\
(85.00)\end{array}$ & $\begin{array}{c}18 \\
(15.00)\end{array}$ \\
\hline 14. & $\begin{array}{l}\text { ICT provides weather related } \\
\text { information }\end{array}$ & $\begin{array}{c}120 \\
(100)\end{array}$ & $\begin{array}{c}0 \\
(0)\end{array}$ \\
\hline 15 & $\begin{array}{l}\text { Do ICT tools provide information } \\
\text { regarding government policies, } \\
\text { programme, and crop insurance } \\
\text { schemes? }\end{array}$ & $\begin{array}{c}96 \\
(80.00)\end{array}$ & $\begin{array}{c}24 \\
(20.00)\end{array}$ \\
\hline 16. & $\begin{array}{l}\text { Minimum knowledge of ICT is } \\
\text { required to use ICT tools }\end{array}$ & $\begin{array}{c}120 \\
(100)\end{array}$ & $\begin{array}{c}0 \\
(0)\end{array}$ \\
\hline
\end{tabular}


Table.2 Distribution of respondents according to their level of overall knowledge towards ICT

\begin{tabular}{|c|c|c|c|}
\hline Category & Score & Frequency & Per cent \\
\hline Low & $<33.33$ & 8 & 6.66 \\
\hline Medium & $33.34-66.66$ & 63 & 52.50 \\
\hline \multirow[t]{2}{*}{ High } & 66.67 and above & 49 & 40.83 \\
\hline & TOTAL & 120 & 100 \\
\hline Mean & & SD & 18.68 \\
\hline
\end{tabular}

Table.3 Correlation coefficient values of independent variables in relation to their knowledge

\begin{tabular}{|c|c|c|}
\hline Sr. No & Variables & Co-relation coefficient \\
\hline 1 & Age & $-0.013^{\mathrm{NS}}$ \\
\hline 2. & Education & $0.178 *$ \\
\hline 3. & Land holding & $0.151^{\mathrm{NS}}$ \\
\hline 4. & Annual income & $0.088^{\mathrm{NS}}$ \\
\hline 5. & Social participation & $0.501 * *$ \\
\hline 6. & Extension contact & $0.509 * *$ \\
\hline 7. & Source of information & $0.467 * *$ \\
\hline 8. & Innovativeness & $0.201 *$ \\
\hline 9. & Risk preference & $0.481 * *$ \\
\hline 10. & Availability of ICT tools & $0.364 * *$ \\
\hline
\end{tabular}

\section{Relationship characteristics of farmers and their knowledge gained towards ICT}

To enumerate existing relation between independent variables and knowledge of farmers, the correlation co-efficient was used to work out and test their statistical significance. The correlation co-efficient of 10 independent variables with knowledge of the farmers were worked out and are presented in Table 2.

Variables such as social participation, extension contact, source of information, risk preference and availability of ICT tools had positive and highly significant relationship with knowledge of respondents at one cent level of significance it may be due the reason that a person with good knowledge will mostly keep good contacts and prefer risk while, education and innovativeness had positive and significant relationship with knowledge of respondents at five per cent level, and remaining variables such as land holding, annual income were found to have non-significant relation with knowledge and variable age was found to have negatively non-significant relationship with knowledge of the respondents (farmers) about ICT tools, these findings were inconformity with Hammudar et al., (2018) (Table 3).

In conclusion it is evident from the study that the majority of the respondents had medium level of knowledge about ICT tools. It was found that majority of the farmers depend on television and mobile phones for getting wide range of agriculture information because of its approachability and convenience of usage, 
Whereas the new ICT tools like internet, smart phones, computer and video conferences they have comparatively less knowledge, since other tools can also bring a considerable change in information availability and its adoption. Hence there is a need to provide farming information through other tools also, as internet occupies larger space in new world and all these tools offers you two-way communication with wider reach and retrievable data. Hence there is requirement of setting awareness centres about ICT by starting ICT initiated programmes of providing information at village level and making ICT as a common source for gathering information and providing subsidy schemes, awareness.

The pooled data is evident that the correlation co-efficient of Knowledge to its independent variables is significant with education, extension contact, social participation, source of information, innovativeness, risk preference, availability of ICT tools.

\section{References}

Devaraja, S.C, 2011. A Study on Knowledge and Attitude of Farmers Using ICT tools for Farm Communication. M.Sc. (Ag.) Thesis. University of Agricultural Sciences GKVK, Bengaluru.

Munyua, H, 2000. Application of Information Communication Technologies in the
Agricultural Sector in Africa: A Gender Perspective In: Rathgeber, E. and Adera, E.O. (Eds). Gender and Information Revolution in Africa, IDRC/ECA. 17 pp. 85-123.

Palaiah, R. K., S. M. Bharatesh, S. Dechamma and K. Devaraja, 2016. Attitude of Farmers about Use of ICT tools in Farm Communication. 21 ${ }^{\text {st }}$ International Academic Conference, Miami. 101-111.

Raghuprasad, K. P; S. C. Devaraja and Y. M. Gopala, 2013. An Analysis of Knowledge Level of Farmers on Utilisation of ICT Tools for Farm Communication. Journal of Rural Development, Vol.32, No.3, Ju ly-

Sept:2013www.researchgate.net/public ation/2986630151

Rahman, M., Nasir Uddin, Khan, M. Suzan. (2018). Factors influencing Farmers' Knowledgeon Information and Communication technology in receiving Agricultural Information in Bangladesh. Bangladesh Journal of Extension Education Vol. 28, No. 1\&2, 2016: 13-19.

Shraddha, B, Kamini Bisht, S. P Singh and Sheela Raghuwanshi, 2018. Pradesh. Journal of Pharmacognosy and Phytochemistry, 7(6): 2493-2521.

\section{How to cite this article:}

Sriker Reddy, G., S. L. Deotale and Mane, S. D. 2020. Knowledge of Farmers Regarding Information and Communication Technology. Int.J.Curr.Microbiol.App.Sci. 9(12): 2509-2513. doi: https://doi.org/10.20546/ijcmas.2020.912.298 